\title{
Assessment of Physico-Chemical Parameters of River Ganga at Allahabad With Respect To WQI
}

\author{
Ruby Pandey ${ }^{1}$, Divya Raghuvanshi ${ }^{1}$, D.N Shukla ${ }^{1}$ \\ ${ }^{1}$ Department of Botany, University of Allahabad, Allahabad, Uttar Pradesh, India
}

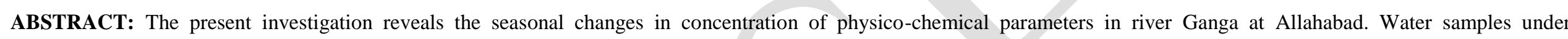

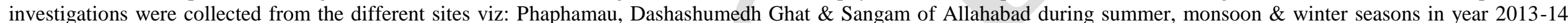

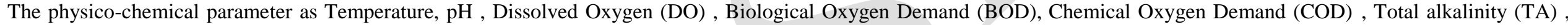

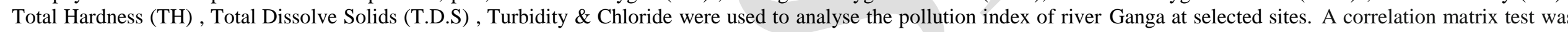

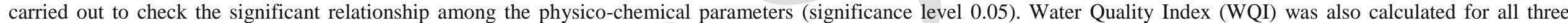
sampling sites at Allahabad in three seasons. The results revealed that the water quality was severely polluted in monsoon and moderately polluted in winter season.

KEYWORDS: River Ganga, Physico-chemical properties, Correlation, Water quality index (WQI).

\section{INTRODUCTION}

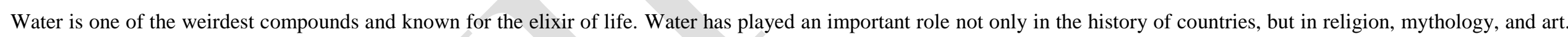

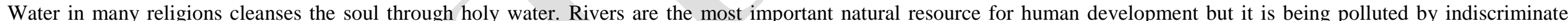

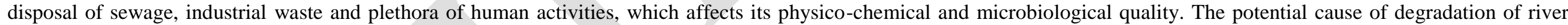

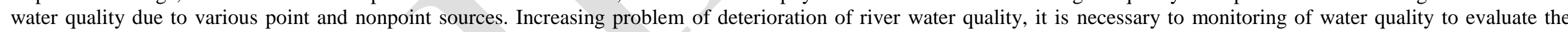

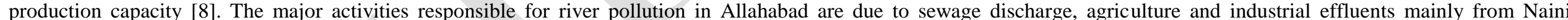

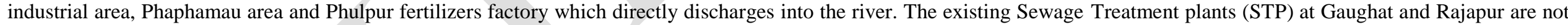

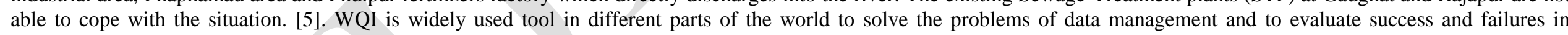

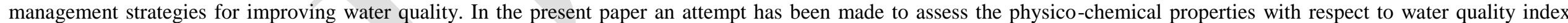
(WQI) in three seasons viz: summer, monsoon and winter during 2013-14 at three selected sites of Allahabad viz: Phaphamau, Dashashumedh Ghat and Sangam. 
ISSN: 2319-8753

International Journal of Innovative Research in Science, Engineering and Technology

(An ISO 3297: 2007 Certified Organization)

Vol. 3, Issue 9, September 2014

\section{MATERIAL AND METHODS}

2.1 Study Area

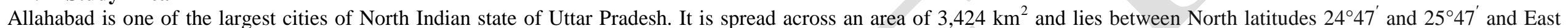

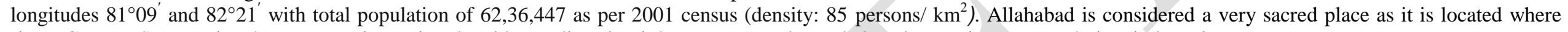
rivers Ganges, Saraswati and Yamuna unite. Being the oldest Indian city, it has many temples and also plays an important role in Hindu scriptures.

Figure 1: Map of Uttar Pradesh showing Allahabad city and an enlarged view of Allahabad city showing study sites

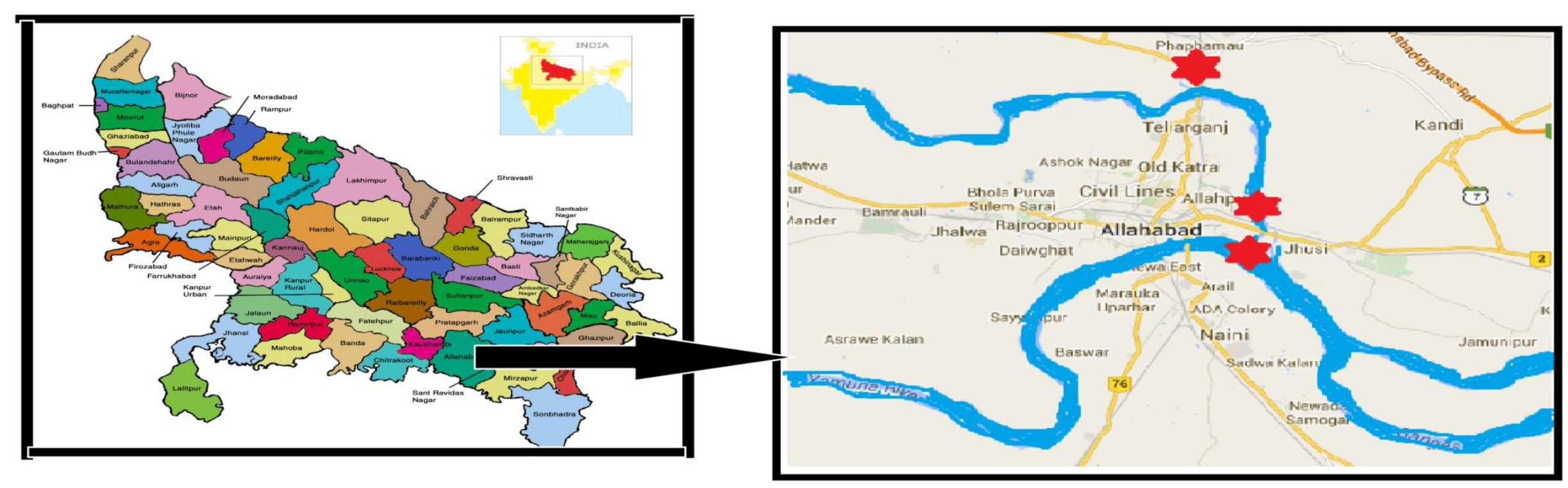




\section{International Journal of Innovative Research in Science, Engineering and Technology}

\section{(An ISO 3297: 2007 Certified Organization)}

\section{Vol. 3, Issue 9, September 2014}

\subsection{Sample collection}

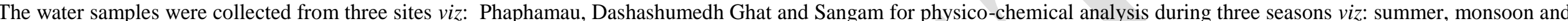

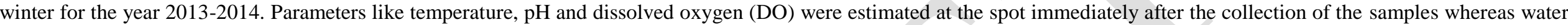
analysis relating to other chemical factors was done in the laboratory.

\subsection{Physico-chemical analysis}

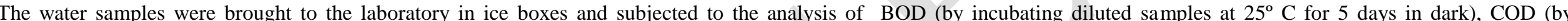

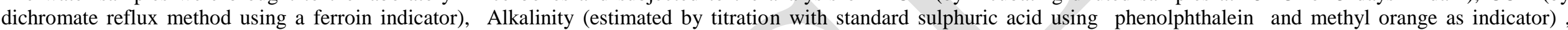

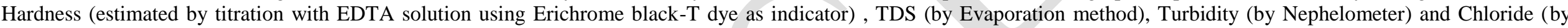
Mohr's argentometric method using Potassium chromate as indicator)

\subsection{Calculation of WQI}

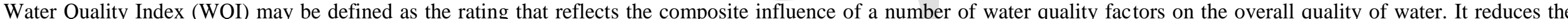

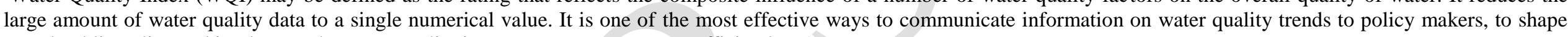
sound public policy and implement the water quality improvement programmes efficiently. [16]

Different water parameter were considered for calculation of water quality index [4] [7] [10] [11] [13] [14]

Water Quality Index (WQI) = इqiwi

Where qi (water quality rating) $=100 \mathrm{X}(\mathrm{Va}-\mathrm{Vi}) /(\mathrm{Vs}-\mathrm{Vi})$

When $\mathrm{Va}=$ actual value present in the water sample

$\mathrm{Vi}=$ ideal value ( 0 for all parameters except $\mathrm{pH}$ and $\mathrm{DO}$ which are 7.0 and $14.6 \mathrm{mg} 1-1$ respectively).

$\mathrm{Vs}=$ standard value

If quality rating qi $=0$ means complete absence of pollutants,

While $0<$ qi $<100$ implies that, the pollutants are within the prescribed standard

When Qi> 100 implies that the pollutants are above the standards.

$\mathrm{Wi}($ Unit weight $)=\mathrm{K} / \mathrm{Sn}$. 


\section{International Journal of Innovative Research in Science, Engineering and Technology}

(An ISO 3297: 2007 Certified Organization)

Vol. 3, Issue 9, September 2014

\section{Where K (constant)}

$\mathrm{Sn}=$ ' $\mathrm{n}$ ' number of standard values.

According to Sinha et al., (2004), the range of water quality index (WQI) is given in Table-1.

TABLE 1: Categories the water quality index (WQI) with range of pollution.

\begin{tabular}{|c|c|c|}
\hline Category & WQI & Range of Pollution \\
\hline I. & $<50$ & Slightly polluted \\
\hline II. & $51-80$ & Moderately polluted \\
\hline III. & $80-100$ & Excessively polluted \\
\hline IV. & $>100$ & Severely polluted \\
\hline
\end{tabular}

\section{RESULT AND DISCUSSION}

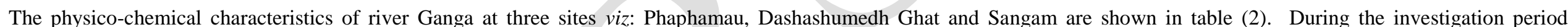

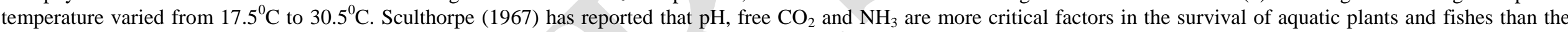

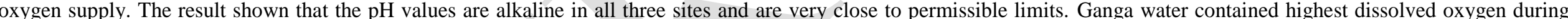

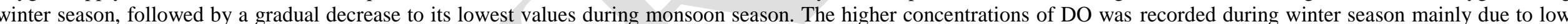

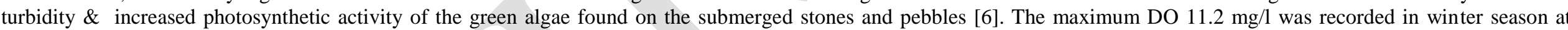

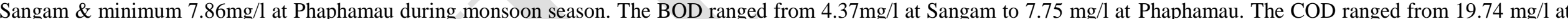

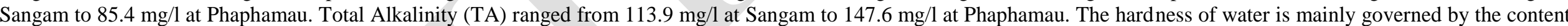

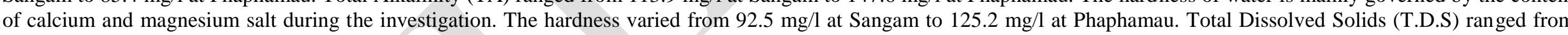

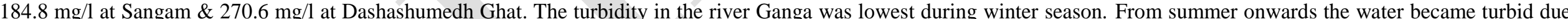

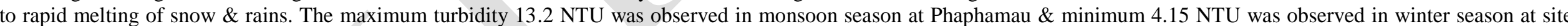

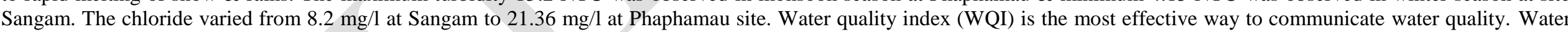

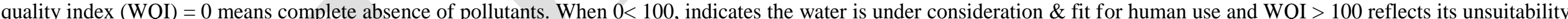

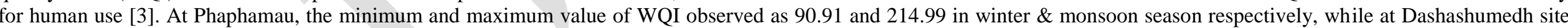




\section{International Journal of Innovative Research in Science, Engineering and Technology}

\section{(An ISO 3297: 2007 Certified Organization)}

\section{Vol. 3, Issue 9, September 2014}

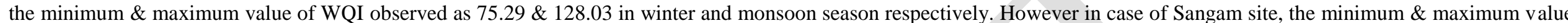

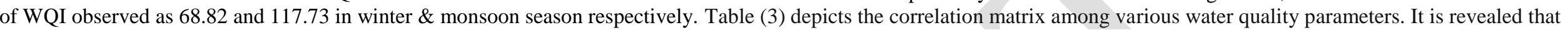

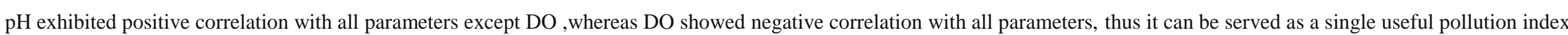
of water quality, as with rise in the value of these parameters decreases the DO concentration.[9]

TABLE 2: Water quality index (WQI) with using specific physico-chemical parameters at three selected sites of Allahabad.

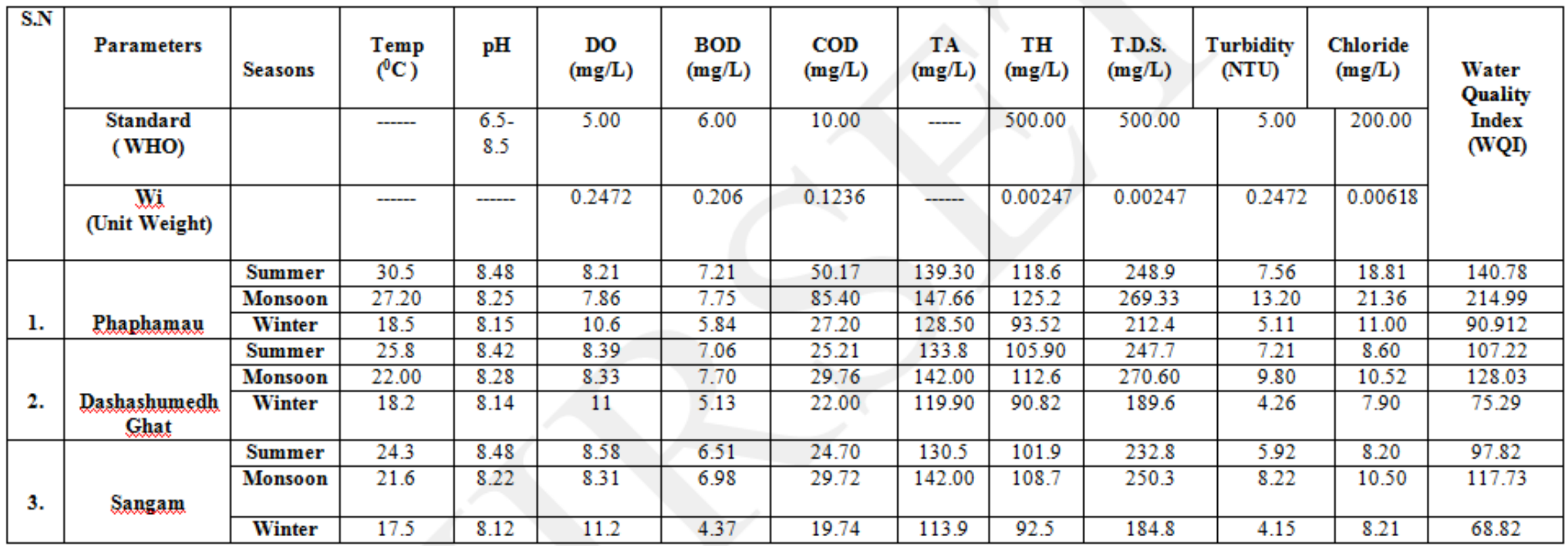


International Journal of Innovative Research in Science, Engineering and Technology

(An ISO 3297: 2007 Certified Organization)

Vol. 3, Issue 9, September 2014

Figure 2: Seasonal changes in concentration of taken physico-chemical parameters with respect to WQI of River Ganga at three sites of Allahabad.

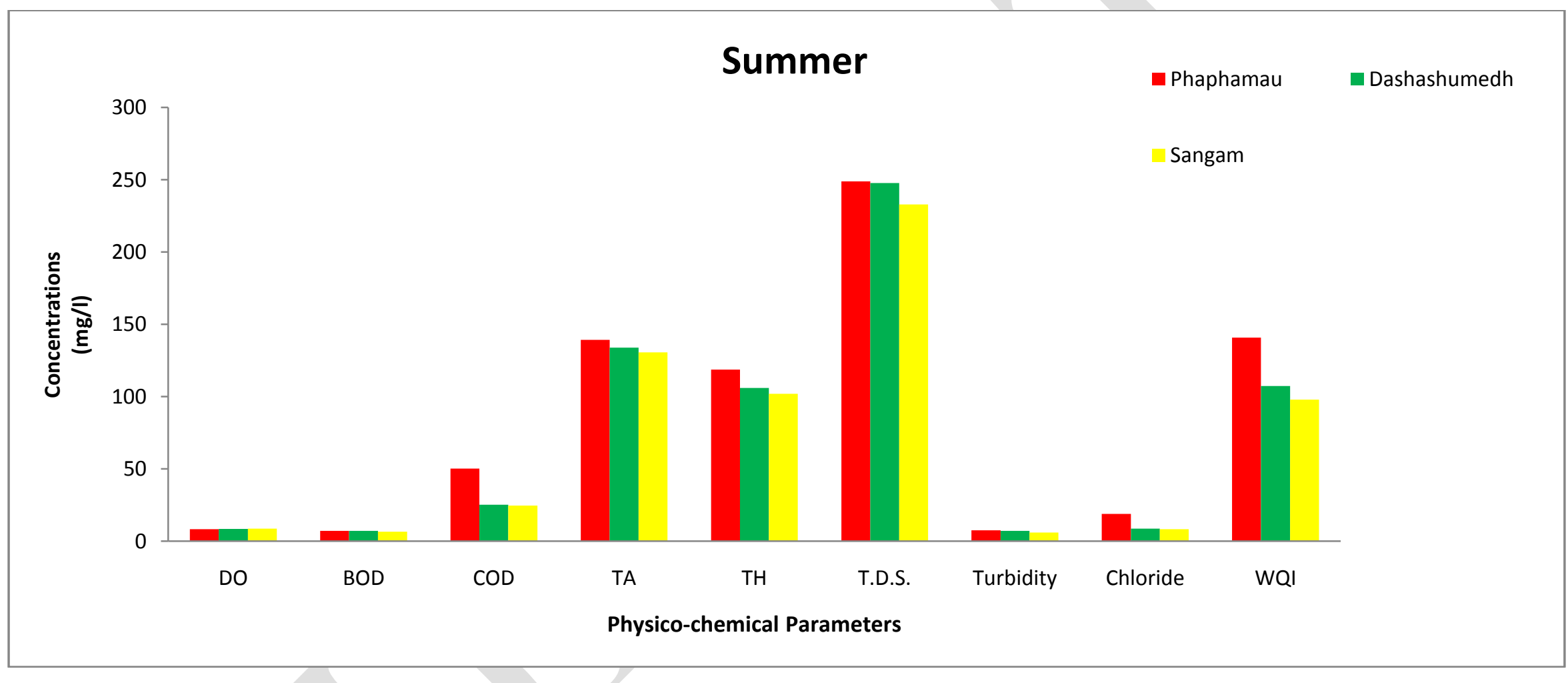


International Journal of Innovative Research in Science, Engineering and Technology (An ISO 3297: 2007 Certified Organization)

Vol. 3, Issue 9, September 2014

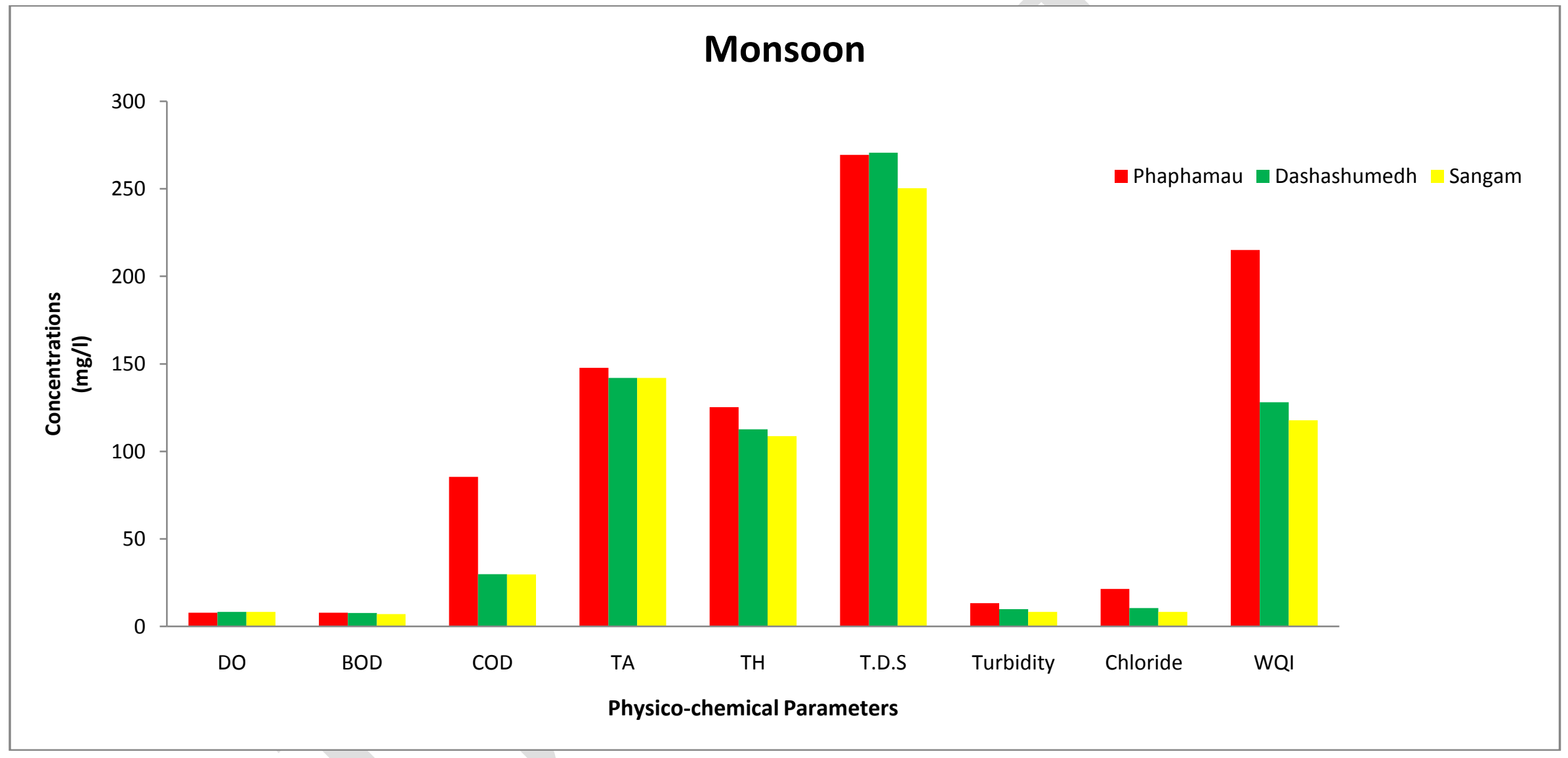


International Journal of Innovative Research in Science, Engineering and Technology

(An ISO 3297: 2007 Certified Organization)

Vol. 3, Issue 9, September 2014

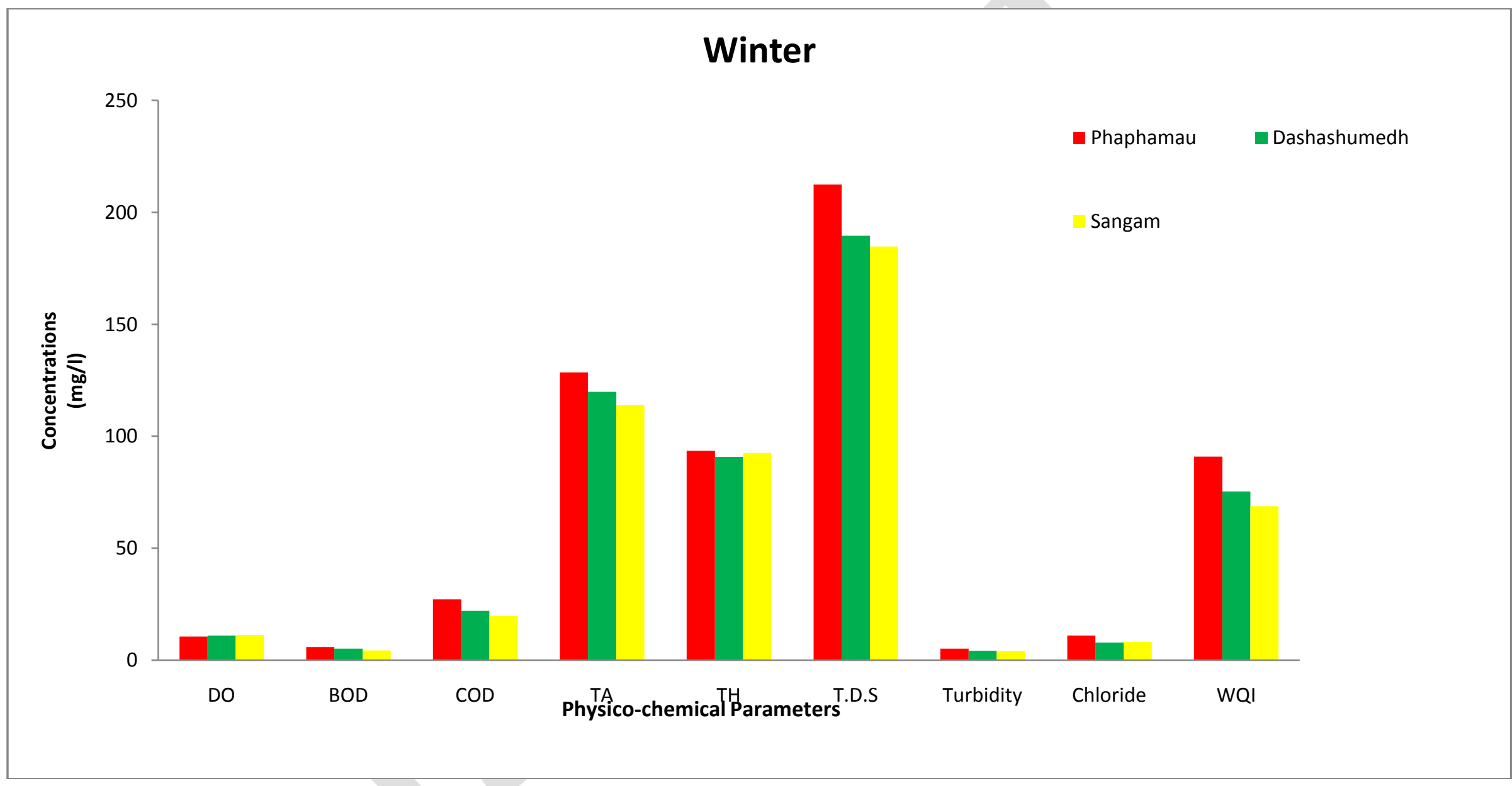




\section{International Journal of Innovative Research in Science, Engineering and Technology}

(An ISO 3297: 2007 Certified Organization)

Vol. 3, Issue 9, September 2014

TABLE 3: Correlation matrix among the various physico-chemical parameters (significant level at 0.05 )

Parameters

Temperature

pH

DO

BOI

COID

TA

TH

T.I.S

Turbidity

Chloride

Temperature 1

pot

.947

$-.901$

BOI

COID

.825

.524

TA

$$
.704
$$

TH

T.D.S

Turbidity

Chloride

$$
\begin{aligned}
& .790 \\
& .783
\end{aligned}
$$

.533

.672

1
-.714
.600
.224
.439
.552
.542
.233
.399

1
-.989
-.842
-.943
-.978
-.975
-.847
-.927

1
.914
.982
.998
.997
.918
.973

1
.974
.936
.940
$1.000^{\star x}$
.983

$\begin{array}{cc}1 & \\ .992 & 1 \\ .993 & 1.000 \\ .976 & .940 \\ .999^{*} & .985\end{array}$

1
.944
.987

\section{CONCLUSION}

From the above analysis, it can be concluded that the water quality of river Ganga at Allahabad during study period, revealed that the water is not suitable for drinking purposes.

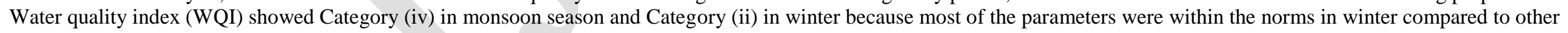


ISSN: 2319-8753

\section{International Journal of Innovative Research in Science, Engineering and Technology}

\section{(An ISO 3297: 2007 Certified Organization)}

\section{Vol. 3, Issue 9, September 2014}

seasons. Its evaluation will not only be helpful to understand the seasonal quality of water but also has advantages for government agencies and institutions where regular water quality data is required.

\section{ACKNOWLEDGEMENT}

The authors are grateful to INSPIRE-DST for providing financial assistance.

\section{REFERENCES}

. APHA, Clescerl, L. S., Greenberg, A. E., Eaton A. D. (1998). Standard Methods for Examination of Water \& Wastewater (20th edn.). Washington, DC.

2. Avnish Chauhan and Suman Singh (2010). "Evaluation of Ganga water for drinking purpose by water quality index at Rishikesh, Uttarakhand, India" Report and Opinion 2010; 2(9):53-61.

3. Bahera, H., Pal, L. and Rout, S.P. (2004). Seasonal variations in the water quality index for Vani Vihar leke in Bhuvaneshwar. In: Water pollution (Ed: Aravind Kumar). A.P.H. Publ. Corp, New Delhi. Pp. 199-209

Harkins, R. D. (1974): An objective water quality index. J. water pollut. Contr. Fedr., 46, 589.

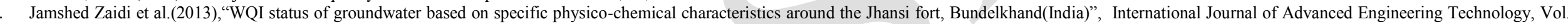
IV,Issue II, pg.17-19

6. Joshi, D.M., Kumar, A. and Agarwal, N. (2009). Studies on physcochemical parameters to assess the water quality of river Ganga for drinking purpose in Haridwar district. Rasayan J. Chem. 2(1), 195-203.

7. K.Raja. (2012). Short essay on Ganga River Pollution.

8. Kesharwani etal. (2004). Determination of water quality index (WQI) of Amkhera pond of Jabalpur city (M.P.). Ntl. J. Life Sci., 1, 61-66.

9. Khaiwal etal. (2003). Seasonal variations in physico-chemical characteristics of River Yamuna in Haryana and its ecological best-designated use. Journal of Environmental Monitoring, 5, 419-426.

10. Mishra, A. etal. (2009). Seasonal and Temporal Variations in Physico-chemical and Bacteriological Characteristics of River Ganga in Varanasi. Int. J. Environ. Res., 3(3):395-402.

11. Mohanta, B.K. etal. Studies in the water quality index of river Sanamachhakananda at Keonjargarh, Orissa, India. Pollut. Res.19, 377-85

12. Padmanabha, B. and Belagali, S.L. (2005). Comparative study on the water quality index of four lakes in the Mysore city. IJEP, 873-876

13. Sculthorpe, C. D. 1967. Biology of Aquatic Vascular plants. Edward Arlold. Pub. Ltd. Londan 610.

14. Tiwari, T.N. and Manzoor, A. (1988). Water quality index for Indian rivers. In Ecology and pollution in Indian rivers (Ed.: R.K. Trivedy). Ashish Publishing House, New Delhi. 271-286.

15. Tiwari, T. N., Das, S. C. and Bose, P.K. (1986). Water quality index for the river Jhelum in Kashmir and its seasonal variations. Pollut. Res., 5, 1-5.

16. Tiwari TN, Mishra M. (1985) A preliminary assignment of water quality index of major Indian rivers, IJEP.;5:276-279.

\section{BIOGRAPHY}

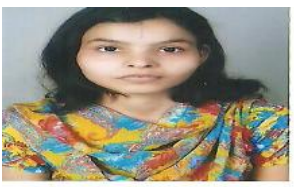

Ruby Pandey is a Research scholar at Botany Department, Allahabad University, Allahabad , India 


\section{International Journal of Innovative Research in Science, Engineering and Technology}

(An ISO 3297: 2007 Certified Organization)

Vol. 3, Issue 9, September 2014

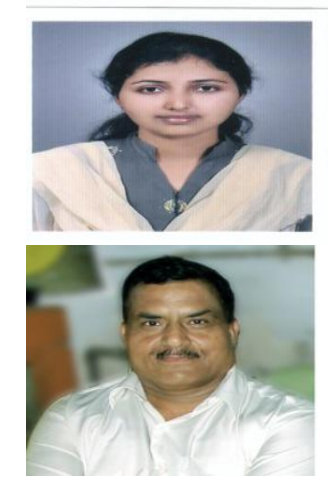

Divya Raghuvanshi is a research scholar at Botany Department, Allahabad University, Allahabad, India.

Prof. D.N Shukla (Supervisor), Botany Department, Allahabad University, Allahabad, India. 